\title{
Quadriceps muscle strength after training with a cycloergometer in patients on hemodialysis
}

\author{
Força muscular de quadríceps após treino com \\ cicloergômetro em pacientes hemodialíticos
}

\section{Fuerza muscular del cuádriceps tras entrenamiento con cicloergómetro en pacientes en hemodiálisis}

\author{
Adriana Linda Abdo®[a], Yvoty Alves dos Santos Sens ${ }^{[a]}$, Luiz Antonio Miorin ${ }^{[a, b]}$, \\ Vivian Bertoni Xavier『[a, b], Antonio de Olival Fernandes ${ }^{[a]}$, Vera Lúcia dos Santos Alves $₫[a, b, c] *$
}

[a] Faculdade de Ciências Médicas da Santa Casa de São Paulo (FCMSCSP), São Paulo, SP, Brazil

[b] Irmandade da Santa Casa de Misericódia de São Paulo (ISCMSP), São Paulo, SP, Brazil

${ }^{[c]}$ Universidade de Mogi das Cruzes (UMC), São Paulo, SP, Brazil

\begin{abstract}
Introduction: Functional disability is common in patients with chronic kidney disease, especially in those on hemodialysis. Muscle strength can be evaluated by a dynamometer; however, no study using this technique on the quadriceps of patients undergoing hemodialysis was found in literature. Objective: To assess the effects of cycloergometer training on the quadriceps muscle strength of patients with chronic kidney disease undergoing hemodialysis. Method: This was a clinical trial including 46 patients, both men and women, over 18 years old who had been undergoing hemodialysis for more than six months and signed an informed consent form. Patients were allocated into two groups: intervention group $(n=22)$ and control group $(n=20)$. The intervention group underwent intradialytic training in a physical therapy protocol with the cycloergometer for two months, whereas the control group, in turn, was only reevaluated two months after the initial evaluation. All patients were assessed for demographic data at baseline and, two
\end{abstract}

\footnotetext{
* ALA: MS, e-mail: adriabdo@gmail.com YASS: PhD, e-mail: yvotys@gmail.com LAM: PhD, e-mail: miorin1@hotmail.com VBX: PhD, e-mail: vivianbxavier@hotmail.com AO: MS; e-mail: olival@uol.com.br VLSA: PhD, fisioterapiasc@uol.com.br
} 
months later for quadriceps muscle strength by standardized dynamometry and with the use of a rigid belt and suction cups. Results: A significant increase was detected in quadriceps muscle strength in the right and left lower limbs in the intervention group when compared with the control group. Conclusion: Quadriceps muscle strength improved after patients with chronic kidney disease on hemodialysis underwent training with the cycloergometer.

Keywords: Muscle Strength. Chronic Renal Insufficiency. Exercise. Physical Therapy Modalities.

\section{Resumo}

Introdução: A incapacidade funcional é comum em pacientes com doença renal crônica, especialmente naqueles em hemodiálise. A força muscular pode ser avaliada pelo dinamômetro, porém não localizamos na literatura estudo dessa técnica em quadríceps de pacientes em hemodiálise. Objetivo: Analisar os efeitos do treinamento com o cicloergômetro na força muscular do quadríceps de pacientes com doença renal crônica em hemodiálise. Método: Este estudo foi prospectivo e randomizado com inclusão de 46 pacientes, acima de 18 anos, de ambos os gêneros que realizavam hemodiálise há mais de seis meses e assinassem o termo de consentimento livre e esclarecido. Os pacientes foram alocados em dois grupos: intervenção $(n=22)$ e controle $(n=20)$. O grupo de intervenção realizou dois meses de treinamento intradialítico de um protocolo fisioterápico com o cicloergômetro, já o grupo controle foi somente reavaliado após dois meses da avaliação inicial. Todos foram avaliados quanto a dados demográficos e força muscular do quadríceps no início e no fim do estudo por dinamometria com padronização da técnica, e uso de cinto rígido e ventosas. Resultados: Houve aumento significante da força muscular de quadríceps em membro inferior direito e esquerdo no grupo intervenção quando comparado ao controle. Conclusão: Houve melhora da força muscular após o treinamento realizado com o cicloergômetro na força muscular do quadríceps de pacientes com doença renal crônica em hemodiálise.

Palavras-chave: Força muscular. Insuficiência renal crônica. Exercício. Modalidades de Fisioterapia.

\section{Resumen}

Introducción: La discapacidad funcional es común en pacientes con enfermedad renal crónica, especialmente aquellos en hemodiálisis. La fuerza muscular se puede evaluar por medio del dinamómetro, pero no hemos encontrado en la literatura un estudio con esta técnica en cuádriceps de pacientes en hemodiálisis. Objetivo: Analizar los efectos del entrenamiento con cicloergómetro sobre la fuerza muscular del cuádriceps de pacientes con enfermedad renal crónica sometidos a hemodiálisis. Método: Se trata de un estudio prospectivo y aleatorizado, en el que incluyó a 46 pacientes, mayores de 18 años, de ambos sexos, que realizaban hemodiálisis durante más de seis meses, y que firmaron el formulario de consentimiento informado. Los pacientes fueron asignados en dos grupos: intervención $(n=22)$ y control $(n=20)$. El grupo intervención realizó dos meses de entrenamiento intradialítico de un protocolo de fisioterapia con el cicloergómetro, mientras que el grupo control fue reevaluado solamente tras dos meses de la evaluación inicial. Todos fueron evaluados en cuanto a los datos demográficos y la fuerza muscular del cuádriceps al principio y al final del estudio por medio de la dinamometría con estandarización de la técnica, y el uso de correas rígidas y ventosas. Resultados: Hubo un aumento significativo en la fuerza muscular del cuádriceps en las extremidades inferiores derecha e izquierda en el grupo intervención en comparación con el grupo control. Conclusión: Se observó la mejora de la fuerza muscular tras el entrenamiento con cicloergómetro en la fuerza muscular del cuádriceps de pacientes con enfermedad renal crónica en hemodiálisis.

Palabras clave: Fuerza muscular. Insuficiencia renal crónica. Ejercicio. Modalidades de Fisioterapia. 


\section{Introduction}

Functional disability is a frequently observed trait in patients with chronic kidney disease (CKD) and prevalent in those requiring some type of renal replacement therapy such as hemodialysis (HD) [1]. Several studies demonstrated [2-5] diminished capacity in the activities of daily living and performance in maximum or submaximal exertion tests in this population.

The pathophysiological explanation for this condition is that the uremic syndrome causes changes to several systems as it progresses, including the cardiorespiratory and muscular systems $[2,5]$. Thus, complaints of generalized fatigue, and dyspnea should be considered as indicative of the need for referring these patients to rehabilitation $[5,6]$.

In the literature, rehabilitation programs are recommended in the pre-, intra- or postdialytic period, but the adherence to protocols and their effectiveness as to their impact on patients' quality of life, functional capacity, and muscle-strength recovery are still vague in terms of reproducibility [5-8]. This controversy derives from a series of tests for evaluating peripheral muscle strength; however, no technique is considered the "golden standard" [8].

The study and analysis of muscle strength by dynamometry are adequate for CKD patients undergoing $\mathrm{HD}$, with the extra benefit of standardization of effectiveness evaluation and reproducibility. Therefore, this study sought to assess the effects of aerobic training using the cycloergometer on the quadriceps muscle strength of patients with chronic kidney disease on hemodialysis.

\section{Method}

Setting, ethics and participants

A cohort of 46 patients undergoing hemodialysis at the dialysis sector of a public university hospital in São Paulo, SP, Brazil, was evaluated after approval from the Research Ethics Committee (CAEE number 41799915.5.0000.5479 and Clinical Trials number NCT \# 02834026).

Patients aged $\geq 18$ years, having undergone hemodialysis for more than six months, clinically stable, without a previous or current record of lung, muscle/joint or neurological disease, were included after agreeing to participate and giving voluntary informed consent.
Those requiring any surgical intervention up to six months before or during the protocol, showing any cardiac decompensation, using continuous or night-time oxygen and using an assistive gait device, prostheses or orthoses for the lower limbs, were excluded.

All patients underwent the same hemodialysis protocol for four hours, three times a week, using polysulfone membrane (Fresenius) and a standard bicarbonate solution (sodium: $138.0 \mathrm{mEq} / \mathrm{L}$; potassium: $2.0 \mathrm{mEq} / \mathrm{L}$; calcium: $2.5 \mathrm{mEq} / \mathrm{L}$; magnesium: $1.0 \mathrm{mEq} / \mathrm{L}$; chloride: $108.5 \mathrm{mEq} / \mathrm{L}$; acetate: $3.0 \mathrm{mEq} / \mathrm{L}$; bicarbonate: $32.0 \mathrm{mEq}$ ).

All participants were evaluated by the same examiner throughout a blind study. Data such as participants' body mass index (BMI), age, sex, time on hemodialysis, disease etiology and dominant lower limb were collected with the aid of a standardized form.

Laboratory tests such as creatinine $(\mathrm{mg} / \mathrm{dL})$ and urea $(\mathrm{mg} / \mathrm{dL})$ were obtained from the patients' medical records, as well as the $\mathrm{Kt} / \mathrm{V}$ value (a measure of hemodialysis dosage). After the initial evaluation, the patients were allocated either into the intervention group $(n=23)$ or the control group $(n=23)$. Confidentiality was ensured by using sealed opaque envelopes containing the number sequences for randomization generated by the java.util software.

\section{Outcome assessment: dynamometry}

The evaluation and reevaluation of quadriceps muscle strength in all patients in both groups was performed by using a manual dynamometer (MicroFET 2, Draper - USA). The device was attached to the limb with the aid of a rigid belt and secured to the site by a suction cup at a fixed point with the patient seated. This means that the examiner does not need to be present, and the dynamometer records the measurement without any interaction with the researcher. All measurements were taken from both the right and left limbs, and knee extension was tested as described by Thorborg et al. in 2010 [8].

\section{Training protocol}

The patients in the control group were evaluated and reevaluated two months later, and followed the dialysis unit's routine, including fistula care, diet and maintaining daily activity. This group was not offered any type of exercising. The intervention group 
underwent 24 training sessions three times a week for eight consecutive weeks in the intradialytic period.

Training was initiated one hour after the beginning of the hemodialysis and continuously monitored with a frequency meter throughout the protocol. The training consisted of 10-minute warm-up with active exercises for the lower and upper limbs in seated position, 30-minute activity on a cycloergometer (ACTE, Mini Bike) positioned in front of the patient's chair, followed by a 10-minute cool-down with the ergometer rotation gradually decreasing until the heart rate (HR, in $\mathrm{bpm}$ ) and blood pressure (BP, in $\mathrm{mmHg}$ ) returned to parameters close to the initial ones [5].

The movement made on the ergometer had the intensity necessary to keep HR between $50 \%$ and $70 \%$ of maximum heart rate (maxHR), which was estimated using the Karvonen et al. [9] formula ( $\operatorname{maxHR}=220$ age in years) and maintained throughout the protocol.

Statistical analysis

Statistical Package for Social Sciences (SPSS) software (version 13.1.) was used for analyzing the database. Qualitative variables were assessed by using the Chi-squared test. The t-test was used in parametric measurements within the group for the quantitative variables, and the Wilcoxon and MannWhitney (WMW) test for comparisons between the intervention and control groups. A 5\% significance level was adopted in the study.

\section{Results}

This study sample was comprised of 46 patients randomized into an intervention group $(n=23)$ and a control group $(\mathrm{n}=23)$.

Allocation and follow-up of all the participants is described in a flowchart according to the template suggested by Consolidated Standards of Reporting Trials -CONSORT (2017) [10], as shown in Figure 1.

Table 1 shows the two groups were homogeneous regarding the age, $\mathrm{BMI}$, time on hemodialysis, Kt/V, creatinine and urea when compared with each other in the evaluation.

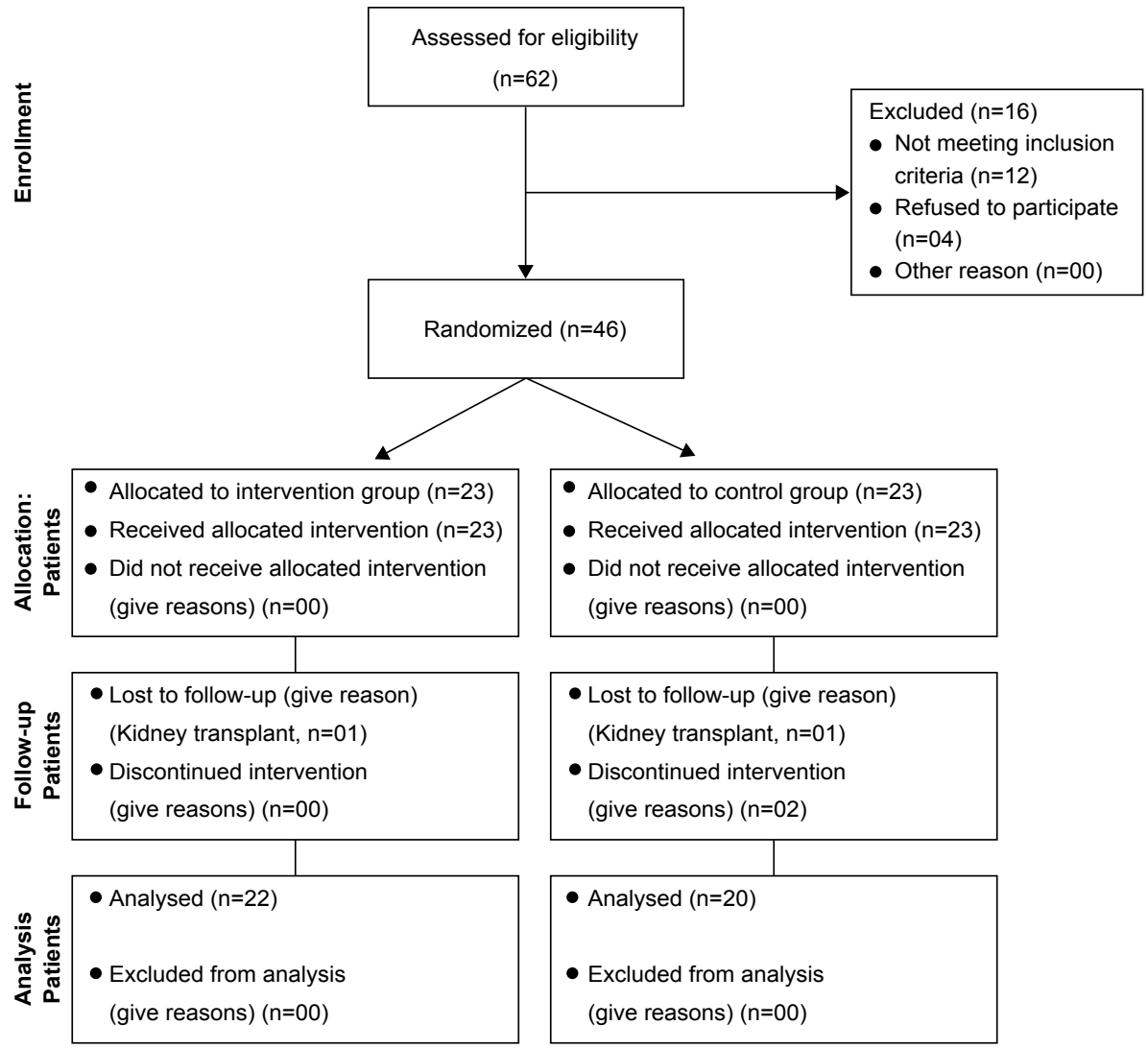

Figure 1 - Flowchart representing the recruitment of research participants, sample distribution, group division for treatment and data analysis. 
Table 1 - Comparison of anthropometric and laboratory variables in the evaluation of patients in the intervention (I) and control (II) groups

\begin{tabular}{|c|c|c|c|c|c|c|}
\hline Variable & Group & $\mathrm{n}$ & Median & Minimum & Maximum & $p$ \\
\hline \multirow{2}{*}{ Age (years) } & 1 & 22 & 40.50 & 28.00 & 62.00 & \multirow{2}{*}{0.488} \\
\hline & $\|$ & 20 & 40.00 & 30.00 & 61.00 & \\
\hline \multirow{2}{*}{ BMI $\left(\mathrm{kg} / \mathrm{m}^{2}\right)$} & 1 & 22 & 22.80 & 18.42 & 28.44 & \multirow{2}{*}{0.061} \\
\hline & $\|$ & 20 & 22.28 & 19.20 & 25.72 & \\
\hline \multirow{2}{*}{ Time on HD (years) } & 1 & 22 & 5.00 & 2.00 & 17.00 & \multirow{2}{*}{0.279} \\
\hline & $\|$ & 20 & 6.00 & 3.00 & 16.00 & \\
\hline \multirow{2}{*}{$\mathrm{Kt} / \mathrm{V}$} & 1 & 22 & 1.42 & 0.98 & 1.91 & \multirow{2}{*}{0.405} \\
\hline & $\|$ & 20 & 1.21 & 0.98 & 1.83 & \\
\hline \multirow{2}{*}{ Creatinine (mg/dL) } & 1 & 22 & 9.98 & 6.20 & 18.20 & \multirow{2}{*}{0.659} \\
\hline & $\|$ & 20 & 10.61 & 6.10 & 18.20 & \\
\hline \multirow{2}{*}{ Urea (mg/dL) } & 1 & 22 & 146.05 & 61.00 & 243.00 & \multirow{2}{*}{0.724} \\
\hline & $\|$ & 20 & 150.30 & 93.00 & 215.00 & \\
\hline
\end{tabular}

In total, 12 women were allocated in the intervention group and 11 in the control group, and the comparison between the two groups yielded a $p=0.976$. The dominant lower limb was predominantly the right one, as observed in 16 patients in the intervention group and in 14 in the control group, with $p=0.845$.

The cause of CKD was unknown in many patients. Among the known causes, hypertensive nephropathy accounted for $54.6 \%$ of the etiological causes of CKD in the intervention group, whereas this prevalence was $55 \%$ in the control group.

The mean quadriceps strength at the initial evaluation of the intervention and control groups was
$22.63 \pm 1.04 \mathrm{~kg}$ and $23.37 \pm 1.66 \mathrm{~kg}$, respectively, with $p=0.970$. At the time of reevaluation, the quadriceps strength was $24.26 \pm 5.18 \mathrm{~kg}$ and $23.32 \pm 7.35 \mathrm{~kg}$ in the intervention and control groups, respectively, with $p<0.001$, demonstrating an increase in strength in the intervention group. Figure 2 shows the progression of quadriceps muscle strength on the dominant side between evaluation and reevaluation considering the values of the intervention and control groups.

Table 2 shows a significant difference in the sum of the quadriceps muscle strength values recorded for both right and left sides between the intervention and control groups.

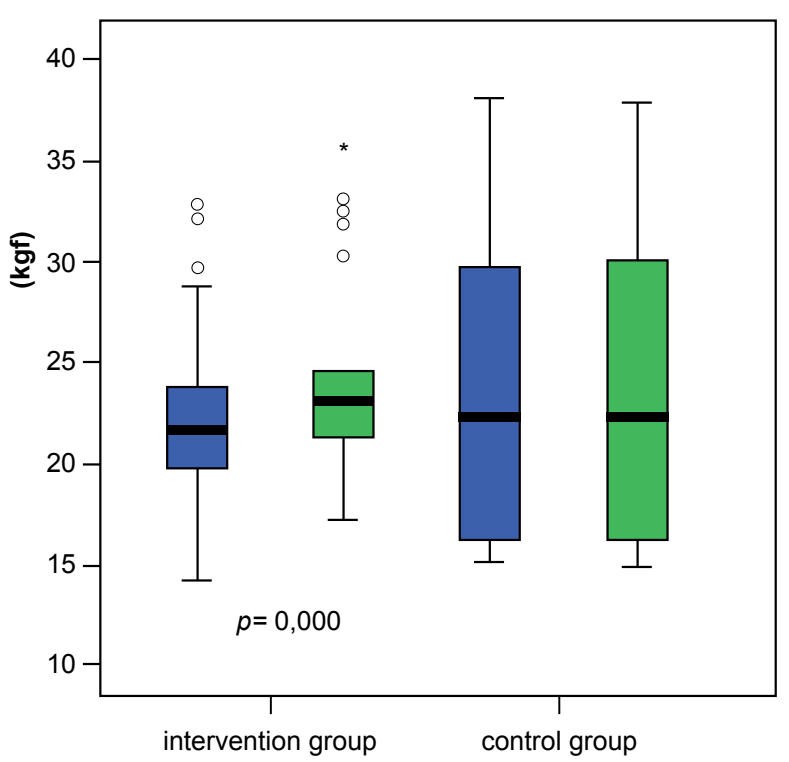

evaluation

$\square$ reevaluation

Figure 2 - Progression of quadriceps muscle strength on the dominant side between evaluation and reevaluation in intervention $(n=22)$ and control $(n=20)$ groups. 
Table 2 - Comparison of the summed values recorded for the right and left sides in the intervention (I) and control (II) groups

\begin{tabular}{ccccccc}
\hline Variable & Group & Number of joints & Median & Minimum & Maximum & $\boldsymbol{p}$ \\
\hline Strength $(\mathrm{kg})$ & $\mathrm{I}$ & 44 & 1.62 & -0.40 & 3.80 & 0.001 \\
& $\|$ & 40 & -0.20 & -0.80 & 1.10 & \\
\hline
\end{tabular}

No adverse effects from exercising were registered in this study.

\section{Discussion}

The objective evaluation of quadriceps muscle strength in patients with CKD undergoing hemodialysis can increase the number of techniques for evaluating rehabilitation protocols used in this population. In this sample, the patients' muscle strength in both right and left lower limbs significantly increased after two months of intradialytic training with the cycloergometer.

On average, the initial sample profile included patients in the fourth decade of life and of both sexes $[2,5]$. Were these patients not in need of hemodialysis, they could be fully engaged in productive activity. However, once they develop CKD, they report functional limitations preventing them from performing their activities of daily living, and the hemodialysis treatment could also be an obstacle for physical activity. Our study shows that training can be performed during hemodialysis and benefits muscle strengthening.

We cannot state that inactivity affects functional ability since the quality of life, level of labor activity or functional capacity were not evaluated. However, several studies affirm that inactivity can lead to a vicious cycle, in which limitation creates an appropriate setting for increasing inactivity $[1-6,11,12]$.

In this study, a similar number of women and men was observed in the groups. This is different from some epidemiological and systematic review studies emphasizing the increased incidence of CKD in women $[2,5,13]$. Instead, the sample of patients from a public hospital in this study had a homogeneous sex distribution, with equal benefits of exercising for men and women.

In this sample, patients with different etiologies for CKD were included. This feature agrees with national data [14], demonstrating the diversity of causal factors and also the high prevalence of hypertension as the initial cause of CKD and subsequent substitutive therapy provided by hemodialysis. Severe metabolic changes were observed at the participants' baseline in this study as in the general population $[12,15,16]$ due to the high urea levels found in these patients $[1,2]$.

As our study progressed, we observed that rehabilitation is positively impacted by several protocols such as those performed with intermittent positive pressure [13] or those with neuromuscular electrostimulation [15]. However, these protocols have limitations to the objective evaluation of the findings regarding the gain of muscle strength since the techniques previously proposed are poorly reproduced [8], despite the great diversity of techniques for muscle strength evaluation. Thus, this study sought to standardize a technique targeting the population with CKD.

The evaluation provided by dynamometry has evolved over the years and today the presence of an examiner is no longer necessary due to many available manners to secure the measuring equipment to the site [8] such as the use of a rigid belt and suction cups in this study. Previously, this examiner would handhold the dynamometer and resist against the patient's movement. This feature caused the test to be considered subjective, since differences in muscle strength readings across examiners [8] rendered them ineffective.

Once the evaluation technique had been standardized, CKD patients on hemodialysis presented higher values of quadriceps muscle strength after an aerobic rehabilitation protocol with the use of the cycloergometer. The increase in muscular strength was credited to the aerobic exercise done with the use of the ergometer in a systematized manner, even without an increase in load. The potential of aerobic activity in patients with various chronic diseases, including CKD, has been reported [18-21]. 
A gain in strength may be a side effect of aerobic activity $[19,21]$ since this protocol did not include any incremental load exercise, which agrees with the findings in a study by Watson et al., who observed [22] that aerobic training in patients with CKD not undergoing dialysis also increases muscle strength when compared with a protocol with resistance exercises. The tension created by the pedaling movement when using the ergometer and possible alteration of the fiber metabolism in muscles can explain the increase in muscle strength [19-21], thereby indirectly generating resistance gain and muscle strength, both observed in the quadriceps of this population.

This study was limited to the analysis of quadriceps strength alone, thus, the effect of training on other lower limb muscle groups, the potential of this type of rehabilitation using a cycloergometer for promoting functional capacity and its impact on the quality of life and labor activities are unknown. Chung et al. [23], in a systematic review of the literature, state that intradialytic exercises can potentially increase physical capacity and have a positive impact on the quality of life. This fact becomes more relevant when the multiple factors responsible for poor quality of life and the high mortality rates are observed among patients who enter hemodialysis programs [24].

The time a patient with CKD phases III and V should spend in a rehabilitation program, is, on average, 12 weeks, as proposed in the literature $[22,23,25]$. Positive effects on quadriceps muscle strength were noticed as early as with 8 weeks of training, 3 times a week.

The impact of the exercise intensity was not evaluated in this protocol since training was based on submaximal heart rate frequency [10]. It is hypothesized that prescribing exercise intensity based on maximum stress tests [2,5] may lead to different answers in our group's future studies since it is known that training with a cycloergometer can impact left ventricular function in patients undergoing hemodialysis [26, 27] and that resistance exercises may benefit the reduction of the inflammatory profile in this population [28].

We emphasize, however, that even with a conservative exercise training intensity and a twomonth protocol, no adverse events occurred during the sessions and this protocol was seen to positively impact muscular strength in patients with CKD under hemodialysis - even in older patients, in whom sarcopenia and protein dysfunction may be more evident $[29,30]$.

\section{Conclusion}

Quadriceps muscle strength improved after patients with chronic kidney disease on hemodialysis underwent training with the cycloergometer.

\section{References}

1. Pierson DJ. Respiratory considerations in patients with renal failure. Respir Care. 2006;51(4):413-22.

2. Segura-Ortí E. Ejercicio en pacientes en hemodiálisis: revisión sistemática de la literatura. Nefrología. 2010;30:336-46.

3. Marcus RL, LaStayo PC, Ikizler TA, Wei G, Giri A, Chen $\mathrm{X}$, et al. Low physical function in maintenance hemodialysis patients is independent of muscle mass and comorbidity. J Renal Nutr. 2015;25:371-5.

4. Herrero JA, Alvarez-Sala JL, Coronel F. Pulmonary diffusing capacity in chronic dialysis patients. Respir Med. 2002;96:487-92.

5. Heiwe S, Jacobson SH. Exercise training in adults with CKD: a systematic review and meta-analysis. Am J Kidney Dis. 2014;64:383-93.

6. Campistol JM. Uremic myopathy. Kidney Int. 2002;62:1901-13.

7. Weiner P, Zidan F, Zonder HB. Hemodialysis treatment may improve inspiratory muscle strength and endurance. Isr J Med Sci. 1997;33:134-8.

8. Thorborg K, Bandholm T, Holmich P. Hip-and knee-strength assessments using a hand-held dynamometer with external belt-fixation are inter-tester reliable. Knee Surg Sports Traumatol Arthrosc. 2013;21:550-5.

9. Karvonen JJ, Kentala E, Mustala O. The effects of training on heart rate: a longitudinal study. Ann Med Exp Biol Fenn. 1957;35:307-15. 
10. Boutron I, Altman DG, Moher D, Schulz KF, Ravaud P. CONSORT Statement for Randomized Trials of Nonpharmacologic Treatments: a 2017 Update and a CONSORT Extension for Nonpharmacologic Trial Abstracts. Ann Intern Med. 2017;4:40-7.

11. Headley S, Germain M, Mailloux P. Resistance training improves strength and functional measures in patients with end-stage renal disease. Am J Kidney Dis. 2002;40(2):355-64.

12. Adams GR, Vaziri ND. Skeletal muscle dysfunction in chronic renal failure: effects of exercise. Am J Physiol Ren Physiol. 2006;290:753-61.

13. Xavier VB, Roxo RS, Miorin LA. Impact of continuous positive airway pressure (CPAP) on the respiratory capacity of chronic kidney disease patients under hemodialysis treatment. Int Urol Nephrol. 2015;47:1011-6.

14. Miranda CCV, Silva RCR, Monteiro HL, Yen LS, Fahur BS. Functional evaluation pre and post physical exercise program for patients in hemodialysis. Medicina (Ribeirão Preto). 2013;46:24-35.

15. Roxo R, Xavier VB, Guimaraes A, Miorin A, Sens YAS, Santos VLS. Impact of neuromuscular electrical stimulation on functional capacity of patients with chronic kidney disease on hemodialysis. J Bras Nefrol. 2016;38:14-20.

16. Howden EJ, Leano R, Petchey W, Coombes JS, Isbel NM, Marwick TH. Effects of exercise and lifestyle intervention on cardiovascular function in CKD. Clin J Am Soc Nephrol. 2013;8:1494-501.

17. Diesel W, Noakes TD, Swanepoel C, Lambert M. Isokinetic muscle strength predicts maximum exercise tolerance in renal patients on chronic hemodialysis. Am J Kidney Dis. 1990;16:109-14.

18. Gierat-Haponiuk K, Haponiuk I, Szalewska D, Chojnicki M, Jaworski R, Niedoszytko P, et al. Effect of complex cardiac rehabilitation on physical activity and quality of life during long-term followup after surgical correction of congenital heart disease. Kardiol Pol. 2015;73:267-73.
19. Paglialonga F, Lopopolo A, Scarfia RV, Consolo S, Galli MA, Salera S, et al. Intradialytic cycling in children and young adults on chronic hemodialysis. Pediatr Nephrol. 2014;29:431-8.

20. Bohm C, Stewart K, Onyskie-Marcus J, Esliger D, Kriellaars D, Rigatto C. Effects of intradialytic cycling compared with pedometry on physical function in chronic outpatient hemodialysis: a prospective randomized trial. Nephrol Dial Transplant. 2014;29:1947-55.

21. Sheng $\mathrm{K}$, Zhang $\mathrm{P}$, Chen $\mathrm{L}$, Cheng J, Wu C, Chen J. Intradialytic exercise in hemodialysis patients: a systematic review and meta-analysis. Am J Nephrol. 2014;40:478-90.

22. Watson EL, Gould DW, Wilkinson TJ, Xenophontos S, Clarke AL, Perez Vogt B, et al. 12-weeks combined resistance and aerobic training confers greater benefits than aerobic alone in non-dialysis CKD. Am J Physiol Ren Physiol. 2018;7:123.

23. Chung YC, Yeh ML, Liu YM. Effects of intradialytic exercise on the physical function, depression and quality of life for haemodialysis patients: a systematic review and meta-analysis of randomised controlled trials. J Clin Nurs. 2017;26:1801-13.

24. Jesky MD, Dutton M, Dasgupta I, Yadav P, NG KP, Fenton A, et al. Health-Related Quality of Life Impacts Mortality but Not Progression to EndStage Renal Disease in Pre-Dialysis Chronic Kidney Disease: a prospective observational study. PLoS One. 2016;10:e165675.

25. Rossi AP, Burris DD, Lucas FL, Crocker GA, Wasserman JC. Effects of a renal rehabilitation exercise program in patients with CKD: a randomized, controlled trial. Clin J Am Soc Nephrol. 2014;5:2052-8.

26. Graham-Brown MPM, March DS, Churchward DR, Young HML, Dungey M, Lloyd S, et al. Design and methods of CYCLE-HD: improving cardiovascular health in patients with end stage renal disease using a structured programme of exercise - a randomised control trial. BMC Nephrol. 2016;17:69. 
27. Aucella F, Valente GL, Catizone L. The role of physical activity in the CKD setting. Kidney Blood Press Res. 2014;39:97-106.

28. Moraes C, Marinho SM, Nobrega AC, Bessa BO, Jacobson $\mathrm{LV}$, Stocker-Pinto MB, et al. Resistance exercise: a strategy to attenuate inflammation and protein-energy wasting in hemodialysis patients? Int Urol Nephrol. 2014;46:1655-62.

29. Greco A, Paroni G, Seripa D, Addante F, Dagostino MP, Aucella F. Frailty, disability and physical exercise in the aging process and in chronic kidney disease. Kidney Blood Press Res. 2014;39:164-8.
30. Musso CG, Jauregui JR, Macías Núñez JF. Frailty phenotype and chronic kidney disease: a review of the literature. Int Urol Nephrol. 2015;47:1801-7.

Received in Mar/05/2018

Recebido em 05/mar/2018

Recibido en 05/mar/2018

Approved in Mar/08/2019

Aprovado em 08/mar/2019

Aprobado en 08/mar/2019 